ORIGINAL PAPER

\title{
OMENTIN SERUM CONCENTRATION AND HEPATIC EXPRESSION IN CHRONIC HEPATITIS C PATIENTS - TOGETHER OR APART?
}

\author{
Michae Kukla ${ }^{1}$, Marek Waluga ${ }^{1}$, Brygida Adamek ${ }^{2}$, Marzena Zalewska-Ziob ${ }^{2}$, \\ Janusz KasperczyK ${ }^{3}$, Andrzej Gabriel ${ }^{4}$, Rafal J. Buldak ${ }^{5}$, Barbara Sobala-Szczygiet ${ }^{6}$, \\ Lucjan Kępa ${ }^{6}$, Katarzyna Ziora ${ }^{7}$, Krystyna Żwirska-KorcZala ${ }^{5}$, Edward Surma ${ }^{1}$, \\ Tomasz SawcZyn ${ }^{5}$, Marek Hartleb ${ }^{1}$
}

\author{
${ }^{1}$ Department of Gastroenterology and Hepatology, Medical University of Silesia, Katowice, Poland \\ ${ }^{2}$ Department of General Biology, Medical University of Silesia, Katowice, Poland \\ ${ }^{3}$ Department of Environmental Medicine and Epidemiology, Medical University of Silesia, Katowice, Poland \\ ${ }^{4}$ Department of Pathomorphology in Zabrze, Medical University of Silesia, Katowice, Poland \\ ${ }^{5}$ Department of Physiology in Zabrze, Medical University of Silesia, Katowice, Poland \\ ${ }^{6}$ Department of Infectious Diseases in Bytom, Medical University of Silesia, Katowice, Poland \\ ${ }^{7}$ Department of Paediatrics in Zabrze, Medical University of Silesia, Katowice, Poland
}

\begin{abstract}
Chronic hepatitis $\mathrm{C}(\mathrm{CHC})$ is accompanied by numerous metabolic disorders, partially associated with altered adipokine system regulation. Omentin (intelectin-1) is a novel adipokine known to play a pivotal role in metabolic regulation in CHC. In a group of $63 \mathrm{CHC}$ patients (29 men/34 women) infected with genotype $1 \mathrm{~b}$, aged $6.6 \pm 14.6$ years, serum omentin levels and its gene expression in liver tissue were examined and their association with metabolic and histopathological features was assessed.

Serum omentin levels were significantly higher in CHC patients compared to controls ( $\mathrm{p}<0.001)$, regardless of sex, body mass index (BMI), insulin sensitivity and lipid concentrations. There was no correlation between serum omentin and omentin hepatic expression. Neither parameter was associated with any histological features. Serum omentin in non-obese CHC patients seems not to be related to metabolic disorders or liver pathology. Omentin hepatic expression shows no relationship with either serum omentin levels or histopathological features. This suggests different mechanisms regulating circulating omentin concentration and omentin hepatic expression in CHC.
\end{abstract}

Key words: omentin, adipokine, chronic hepatitis C, fibrosis, insulin resistance, steatosis, liver.

\section{Introduction}

Adipo(cyto)kines are fat-derived hormones and cytokines fundamental to the pathogenesis of metabolic syndrome (MS) and liver steatosis that play a central role in insulin homeostasis and necro-inflammatory activity $[1,2]$. Adipokines have been suggested to in- fluence liver fibrosis progression [3, 4]. Thus, they are considered to play an important role in interactions between a variety of systems, including adrenal, immune, and central and peripheral nervous systems [5].

Chronic hepatitis $\mathrm{C}$ (CHC), because of concomitant insulin resistance (IR) $[6,7]$, high prevalence of steatosis $[8,9]$, increased prevalence of impaired 
glucose tolerance and/or type 2 diabetes mellitus (T2DM) $[10,11,12]$ and changes in lipid metabolism [13], has been considered not only as a viral disease, but also as a metabolic liver disease. Moreover, IR is a strong predictor of poor response to antiviral therapy, alongside advanced hepatic steatosis and fibrosis $[6,14]$. Numerous reports have demonstrated altered levels of some adipokines such as leptin, adiponectin, resistin, visfatin, vaspin, chemerin and fibroblast growth factor (FGF) 21 in $\mathrm{CHC}$ patients $[4,15,16,17,18,19,20]$.

Yang et al., looking for molecule(s) regulating omental and mesenteric fat depots, indentified a novel 34-kDa adipokine gene which they named omentin [21]. Further analysis established the human omentin gene as consisting of 8 exons and 7 introns, presenting $100 \%$ identity with human intelectin [22]. It is mainly expressed in the vascular fraction of visceral fat depots but is barely detectable in subcutaneous adipose tissue and mature adipocytes $[21$, 23]. Omentin enhances insulin-stimulated glucose transport via increase of protein kinase $\mathrm{B}(\mathrm{PKB} / \mathrm{Akt})$ phosphorylation in human subcutaneous and visceral adipocytes, suggesting the possibility of improving their insulin sensitivity [21]. Activation of adenosine monophosphate-activated protein kinase (AMPK) by omentin may result in inhibition of gluconeogenesis and lowering glucose levels [24]. Omentin has been suggested to exert anti-inflammatory activity. It attenuates C-reactive protein-induced angiogenesis potentially via the nuclear factor $\mathrm{\kappa B}$ signaling pathway, a potent proinflammatory signaling pathway [25]. Additionally, omentin inhibits tumor necrosis factor $\alpha(\mathrm{TNF}-\alpha)$-induced vascular inflammation in human endothelial cells. Omentin-activated AMPK may directly inhibit lymphocyte adhesion to vascular endothelial cells [26]. The major circulating isoform in human plasma is omentin-1, correlating inversely with obesity and IR as determined by homeostasis model assessment for IR (HOMA-IR) yet correlated positively with adiponectin and high-density lipoprotein (HDL) cholesterol levels [27]. Plasma omentin levels were significantly lower in the morbidly obese, and they correlated inversely with glucidic metabolism parameters, while expression in visceral adipose tissue was significantly lower in morbidly obese women than in controls [28]. Circulating concentrations of adipokines, including omentin, were suggested to be sex-dependent, because sex hormones influence adipose tissue metabolism regulation [29]. Schäffler et al. noted important omentin mRNA expression in omental adipose tissue probes from patients with chronic inflammatory bowel diseases, suggesting that this adipocytokine plays a role in the defense against intestinal bacterial translocation in the context of Crohn's disease [22]. Nassif et al. reported elevated serum omentin-1 levels positively associated with the liver enzymes aspartate and alanine aminotransferases (AST and ALT), postulating its implication in the pathogenesis and metabolic complications of $\mathrm{CHC}$ [30]. According to our best knowledge, there has been only one study that assessed serum omentin concentration in CHC patients, but the liver tissue omentin expression in $\mathrm{CHC}$ patients has not yet been explored.

Thus, the main objectives of this study were to evaluate serum omentin levels and omentin mRNA expression in the liver tissue and to assess their relationship with metabolic parameters and liver histology in men and women diagnosed with CHC.

\section{Material and methods}

\section{Study group}

The study was performed on 63 patients with CHC (29 men/34 women), aged between 19 and 70 years - average $46.6 \pm 14.6$ years. All of the patients were infected with HCV genotype $1 b$. Serum HCV-RNA was assayed with the reverse transcription polymerase chain reaction (RT-PCR) method (Amplicor Roche/Promega v.2 Diagnostic Test, Branchburg, NJ, USA) while virus genotype was assessed by a reverse-hybridization line probe assay (LiPA Versant Test, Milwaukee, WI, USA) and viral load by signal amplification nucleic acid probe assay for the quantitation of human hepatitis $C$ viral RNA [Bayer Versant HCV RNA 3.0 Assay (bDNA); Bayer Diagnostics, Berkeley, CA, USA]. All patients were naive for the antiviral treatment. Patients infected with other HCV genotypes, hepatitis B or HIV co-infection, drug or alcohol abuse and autoimmune, neoplastic, thyroid and psychiatric diseases, as well as diabetes mellitus, and renal or heart failure were excluded from the study.

Study group participants had their systolic and diastolic blood pressure and waist circumference measured. With body mass and height estimations, body mass index (BMI) was calculated. To enable further analysis, subgroups defined as BMI $<25$ and BMI $\geq 25 \mathrm{~kg} / \mathrm{m}^{2}$ were also created. All patients underwent an oral glucose tolerance test for diagnosis of diabetes mellitus or impaired glucose tolerance. On the day of the liver biopsy, a single blood sample was drawn in the morning from all patients subjected to fasting. The samples were centrifuged, and sera were aliquoted and frozen at $-70^{\circ} \mathrm{C}$ until further processing.

The control group consisted of $30(15 \mathrm{men} / 15$ women) healthy persons, with BMI ranging between 20 and 25 , aged $47.9 \pm 14.8$ years $(44.7 \pm 14.9$ and $51.1 \pm 14.5$ years men and women, respectively). A single blood sample in the fasting state was taken in the morning. Liver biopsy was not carried out in the control group. 
The study protocol was approved by the Ethical Committee of the Medical University of Silesia in Katowice, Poland, and conformed to the ethical guidelines of the Declaration of Helsinki. Informed consent was obtained for all study participants.

\section{Biochemical and serological assays}

Biochemical parameters were measured using routine methods. The upper limit of ALT activity was set at $38 \mathrm{IU} / \mathrm{l}$, AST at $40 \mathrm{IU} / \mathrm{l}$, gamma-glutamyltransferase (GGT) activity at $50 \mathrm{IU} / \mathrm{l}$ and total serum bilirubin concentration at $17 \mu \mathrm{mol} / \mathrm{l}$. Insulin concentration was measured with DiaMetra Insulin EIA Kit, Cat. No DKO076 (DiaMetra, Italy). For IR estimation the homeostasis model assessment for IR (HOMA-IR) was calculated by the formula: fasting insulin level $(\mathrm{mUI} / \mathrm{l}) \times$ fasting glucose level $(\mathrm{mg} / \mathrm{dl}) / 405$. With respect to the HOMA-IR value, patients were divided into two subgroups - below and equal to or above 2.5. Serum omentin concentrations were assessed in duplicate by the immunoenzymatic method using the Omentin-1 kit (BioVendor, Czech Republic; cat. no RD 191100200R).

\section{Liver histology}

Liver biopsy was performed with the Hepafix kit (B. Braun, Melsungen AG, Germany) as part of the diagnostic routine before the antiviral therapy. Tissue samples were immediately divided into the higher part for histopathological examination and the smaller one stabilized in RNAlater (Sigma-Aldrich, St. Louis, USA) and frozen at $-80^{\circ} \mathrm{C}$ for further molecular procedures. Biopsy specimens including at least eleven portal tracts were examined independently by two experienced pathologists. Histopathological features were assessed according to Scheuer's (necro-inflammatory activity, fibrosis), Brunt's (steatosis) and Kleiner's (ballooning degeneration) scales [31, 32, 33].

\section{Liver tissue omentin expression}

Total RNA was isolated from liver biopsy specimens of CHC patients using the RNeasy Mini Kit (Qiagen, Hilden, Germany), followed by removing trace amounts of genomic DNA with RNase Free DNase Set (Qiagen, Hilden, Germany). RNA was quantified by measuring the absorbance at 260 and $280 \mathrm{~nm}$ (NanoDrop 1000 Spectrophotometer, Thermo Fisher Scientific, Wilmington, USA) and the integrity was assessed by electrophoresis in $1.2 \%$ ethidium bromide stained agarose gel.

RNA isolates were used for cDNA synthesis by RT reaction. $2 \mu \mathrm{g}$ of total $\mathrm{RNA}$ was reverse transcribed into cDNA in a total volume $20 \mu \mathrm{l}$ using High Capacity RNA-to-cDNA Kit (Applied Biosystems, Foster City, USA) according to the manufacturer's instructions. Received cDNA was used to determine omentin gene expression level by real-time quantitative PCR (RT-Q-PCR) assay (TaqMan system). TaqMan primers and probes for omentin and the housekeeping gene $G A P D H$ were bought as ready to use assays: TaqMan Gene Expression Assays (Hs 00914740_g1 for omentin) and Human GAPD Endogenous Control (FAM/MGB Probe, Non-Primer Limited) for GAPDH (Applied Biosystems, Foster City, USA). RT-QPCR for both genes was performed in a volume 20 $\mu l$ on the ABI PRISM 7300 Real Time PCR Detection System (Applied Biosystems, Foster City, USA). For each run, a RT-Q-PCR mix was prepared on ice containing $10 \mu \mathrm{l}$ of Applied Biosystems Universal PCR Master Mix, $1 \mu \mathrm{l}$ of primers and probe mix and $8 \mu \mathrm{l}$ of $\mathrm{H}_{2} \mathrm{O}$ (Qiagen, Hilden, Germany). To each well of a 96-well plate, $19 \mu \mathrm{l}$ of QRT-PCR mix and $1 \mu \mathrm{l}$ of cDNA samples were added. All PCRs were performed in duplicate. In all amplification reactions, a negative control was also included. Thermal cycling for both omentin and GAPDH was initiated with an incubation step at $50^{\circ} \mathrm{C}$ for $2 \mathrm{~min}$, followed by a first denaturation step at $95^{\circ} \mathrm{C}$ for $10 \mathrm{~min}$, and continued with 40 cycles of $95^{\circ} \mathrm{C}$ for $15 \mathrm{~s}, 60^{\circ} \mathrm{C}$ for $1 \mathrm{~min}$. The standard curves for the housekeeping gene GAPDH and the target gene were generated by serial dilutions of the control cDNA (equivalent to $1 \mu \mathrm{g}$ of total RNA) in four 2-fold dilution steps. The expression levels of omentin and GAPDH genes in every sample were determined from the respective standard curve and the omentin gene expression was divided by the GAPDH gene expression to obtain a normalized target value (relative expression level).

\section{Statistical analysis}

The data are presented as mean \pm SD. Differences between groups were examined through nonparametric tests (Mann-Whitney or Kruskal-Wallis), linear correlation (Spearman) and logistic regression analysis using the Statistica software version 10.0 (StatSoft Inc. USA). For all the analyses, statistical significance was determined for values of $p<0.05$.

\section{Results}

Clinical and demographic data and the comparison of CHC patients with the control group are summarized in Table I. HOMA-IR, but not serum glucose and insulin, was markedly increased in $\mathrm{CHC}$ patients compared to controls (Table I). There were no abnormalities in results of serum biochemical parameters in the control group. Women and men with $\mathrm{CHC}$ participating in our study did not differ from each other according to age or diastolic blood pressure, but importantly men had higher BMI, waist circumference, systolic blood pressure and GGT. It was also noted that there were no obese CHC patients and none of them had been diagnosed with hypertension before. 
Table I. General characteristics of CHC patient group

\begin{tabular}{|c|c|c|c|c|c|c|}
\hline & $\begin{array}{l}\text { CHC PATIENTS } \\
\quad \mathbf{N}=63 \\
\end{array}$ & $\begin{array}{c}\text { MEN } \\
\mathbf{N}=29(46 \%)\end{array}$ & $\begin{array}{c}\text { WOMEN } \\
\mathbf{N}=34(54 \%)\end{array}$ & $\mathrm{P}^{*}$ & Controls & $\mathrm{P} * *$ \\
\hline Age (years) & $46.6 \pm 14.6$ & $48.2 \pm 16.6$ & $45.3 \pm 12.8$ & NS & $47.9 \pm 14.8$ & NS \\
\hline BMI $\left(\mathrm{kg} / \mathrm{m}^{2}\right)$ & $24.8 \pm 3.0$ & $25.7 \pm 2.6$ & $24.0 \pm 3.1$ & 0.02 & $23.9 \pm 3.3$ & NS \\
\hline Waist circumference $(\mathrm{cm})$ & $83.4 \pm 11.9$ & $87.8 \pm 11.2$ & $79.4 \pm 12.5$ & 0.03 & $85.5 \pm 8.7$ & NS \\
\hline $\mathrm{SBP}(\mathrm{mmHg})$ & $129.0 \pm 15.2$ & $135.0 \pm 18.8$ & $125.0 \pm 12.5$ & 0.02 & $115.0 \pm 10.5$ & NS \\
\hline DSP (mmHg) & $79.1 \pm 8.9$ & $79.1 \pm 8.9$ & $80.0 \pm 9.5$ & NS & $77.1 \pm 6.6$ & NS \\
\hline Fasting insulin $(\mu \mathrm{U} / \mathbf{l})$ & $11.6 \pm 9.6$ & $10.6 \pm 6.3$ & $12.4 \pm 11.8$ & NS & $10.0 \pm 4.5$ & NS \\
\hline Fasting glucose (mg/dl) & $93.7 \pm 16.0$ & $95.1 \pm 16.4$ & $92.6 \pm 15.8$ & NS & $80.8 \pm 9.0$ & NS \\
\hline HOMA-IR & $2.9 \pm 2.7$ & $2.5 \pm 1.3$ & $3.4 \pm 3.5$ & NS & $2.0 \pm 0.5$ & 0.03 \\
\hline Total bilirubin $(\mu \mathrm{mol} / \mathrm{l})$ & $14.3 \pm 8.7$ & $15.1 \pm 4.1$ & $13.6 \pm 11.2$ & NS & $9.7 \pm 3.5$ & 0.02 \\
\hline GGT (U/l) & $80.7 \pm 86.9$ & $104.8 \pm 119.2$ & $60.2 \pm 34.5$ & 0.04 & $26.0 \pm 5.5$ & 0.04 \\
\hline $\operatorname{ALT}(\mathrm{U} / \mathbf{l})$ & $75.4 \pm 44.5$ & $83.2 \pm 50.8$ & $98.8 \pm 37.7$ & NS & $25.6 \pm 4.3$ & 0.001 \\
\hline $\operatorname{AST}(\mathrm{U} / \mathrm{l})$ & $51.7 \pm 25.3$ & $54.2 \pm 28.5$ & $59.5 \pm 22.5$ & NS & $24.1 \pm 3.8$ & 0.004 \\
\hline Total cholesterol (mg/dl) & $187.8 \pm 117.1$ & $199.5 \pm 170.6$ & $179.4 \pm 53.8$ & NS & $174.6 \pm 33.2$ & NS \\
\hline LDL cholesterol (mg/dl) & $97.6 \pm 45.6$ & $85.0 \pm 38.3$ & $107.6 \pm 49.0$ & NS & $94.5 \pm 20.2$ & NS \\
\hline HDL cholesterol (mg/dl) & $53.7 \pm 24.6$ & $50.3 \pm 27.8$ & $56.0 \pm 22.3$ & NS & $44.0 \pm 12.8$ & NS \\
\hline Triglycerides (mg/dl) & $131.9 \pm 57.8$ & $136.2 \pm 56.3$ & $129.0 \pm 59.6$ & NS & $139.0 \pm 45.0$ & NS \\
\hline CRP (mg/dl) & $1.7 \pm 1.2$ & $1.6 \pm 1.1$ & $1.8 \pm 1.4$ & NS & $1.5 \pm 1.4$ & NS \\
\hline HCV viral load (IU/l) & $\begin{array}{l}2053301 \\
\pm 364614\end{array}$ & $\begin{array}{l}2781433 \\
\pm 487426\end{array}$ & $\begin{array}{r}1432246 \\
\pm 1976597 \\
\end{array}$ & NS & & \\
\hline Serum omentin $(\mathrm{ng} / \mathrm{ml})$ & $14.68 \pm 4.12$ & $14.55 \pm 4.66$ & $14.84 \pm 3.48$ & NS & $10.51 \pm 3.90$ & $\begin{array}{c}< \\
0.001 \\
\end{array}$ \\
\hline $\begin{array}{l}\text { Omentin hepatic } \\
\text { expression/GAPDH }\end{array}$ & $0.57 \pm 1.27$ & $0.36 \pm 0.56$ & $0.75 \pm 1.64$ & NS & & \\
\hline
\end{tabular}

Serum omentin concentration was significantly higher in CHC patients compared to controls (14.68 \pm 4.12 vs. $10.51 \pm 3.90 \mathrm{ng} / \mathrm{ml}$, respectively, OR 1.30 ; 95\% CI: 1.14-1.49; p < 0.001) (Table I). There was no difference in serum omentin levels and its hepatic gene expression between men and women with CHC (Table I). Similarly, there was no difference in serum omentin levels between men and women in the control group $(10.92 \pm 3.99$ vs. $10.11 \pm 3.91 \mathrm{ng} / \mathrm{ml}$, respectively).

Table II. Linear correlation between serum omentin and omentin expression in the liver tissue

\begin{tabular}{lccc}
\hline & \multicolumn{3}{c}{ Serum OMENTIN [NG/ML] } \\
\cline { 2 - 4 } & MeN & WoMen & $\begin{array}{c}\text { CHC } \\
\text { PATIENTS }\end{array}$ \\
\hline $\begin{array}{l}\text { Liver omentin/ } \\
\text { GAPDH }\end{array}$ & $\mathrm{r}=0.23$ & $\mathrm{r}=-0.16$ & $\mathrm{r}=-0.09$ \\
& $\mathrm{p}=\mathrm{NS}$ & $\mathrm{p}=\mathrm{NS}$ & $\mathrm{p}=\mathrm{NS}$ \\
\hline
\end{tabular}

There was no relationship between serum omentin concentration and its gene expression in the liver in CHC patients, either in the group as a whole or men or women analyzed separately (Table II).

The whole study group included $34(54 \%) \mathrm{pa}-$ tients with BMI $\geq 25 \mathrm{~kg} / \mathrm{m}^{2}$. BMI $\geq 25 \mathrm{~kg} / \mathrm{m}^{2}$ was observed in $17(50 \%)$ females and $17(58.6 \%)$ males. In $\mathrm{CHC}$ patients there were no significant differences in serum omentin levels and omentin expression in liver tissue according to BMI and HOMA-IR either in the study group as a whole or in men or women analyzed separately (Table III).

There was no significant difference in serum omentin levels and omentin hepatic expression in CHC patients with various necro-inflammatory activity, steatosis and hepatocyte ballooning degeneration grades and hepatic fibrosis stage (Table IV). Logistic regression analysis of serum omentin and its gene expression in the liver tissue adjusted for fibrosis, steatosis, necro-inflammatory activity and ballooning degeneration grade showed no significant differences. 
Table III. Serum omentin concentration and omentin hepatic expression in the study participants according to sex, BMI and HOMA-IR

\begin{tabular}{|c|c|c|c|c|c|c|}
\hline & \multicolumn{2}{|c|}{ MEN } & \multicolumn{2}{|c|}{ WOMEN } & \multicolumn{2}{|c|}{ CHC PATIENTS } \\
\hline & $\begin{array}{c}\text { BMI } \\
<25 \mathrm{KG} / \mathrm{M}^{2}\end{array}$ & $\begin{array}{c}\mathrm{BMI} \\
\geq 25 \mathrm{KG} / \mathrm{M}^{2}\end{array}$ & $\begin{array}{c}\text { BMI } \\
<25 \mathrm{KG} / \mathrm{M}^{2}\end{array}$ & $\begin{array}{c}\text { BMI } \\
\geq 25 \mathrm{KG} / \mathrm{M}^{2}\end{array}$ & $\begin{array}{c}\text { BMI } \\
<25 \mathrm{KG} / \mathrm{M}^{2}\end{array}$ & $\begin{array}{c}\text { BMI } \\
\geq 25 \mathrm{KG} / \mathrm{M}^{2}\end{array}$ \\
\hline $\begin{array}{l}\text { Serum omentin } \\
(\mathrm{ng} / \mathrm{ml})\end{array}$ & $14.11 \pm 4.38$ & $15.35 \pm 2.70$ & $14.66 \pm 4.14$ & $14.44 \pm 5.25$ & $14.43 \pm 4.17$ & $14.89 \pm 4.13$ \\
\hline \multirow{2}{*}{$\begin{array}{l}\text { Liver omentin/ } \\
\text { GAPDH }\end{array}$} & $0.40 \pm 0.67$ & $0.33 \pm 0.49$ & $0.33 \pm 0.58$ & $1.17 \pm 2.20$ & $0.36 \pm 0.61$ & $0.75 \pm 1.63$ \\
\hline & $\begin{array}{l}\text { HOMA-IR } \\
<2.5\end{array}$ & $\begin{array}{l}\text { HOMA-IR } \\
\quad \geq 2.5\end{array}$ & $\begin{array}{l}\text { HOMA-IR } \\
<2.5\end{array}$ & $\begin{array}{l}\text { HOMA-IR } \\
\quad \geq 2.5\end{array}$ & $\begin{array}{l}\text { HOMA-IR } \\
<2.5\end{array}$ & $\begin{array}{c}\text { HOMA-IR } \\
\geq 2.5\end{array}$ \\
\hline $\begin{array}{l}\text { Serum omentin } \\
{[\mathrm{ng} / \mathrm{ml}]}\end{array}$ & $14.05 \pm 2.87$ & $15.58 \pm 3,83$ & $14.14 \pm 5.05$ & $14.28 \pm 4.45$ & $14.10 \pm 4.11$ & $14.96 \pm 4.07$ \\
\hline $\begin{array}{l}\text { Liver omentin/ } \\
\text { GAPDH }\end{array}$ & $0.16 \pm 0.11$ & $0.52 \pm 0.88$ & $1.26 \pm 1.97$ & $0.21 \pm 0.16$ & $0.76 \pm 1.53$ & $0.38 \pm 0.65$ \\
\hline
\end{tabular}

There were no significant differences between analyzed subgroups with respect to omentin expression and serum omentin concentration.

Table IV. Serum omentin concentration and omentin hepatic tissue expression in CHC patients according to liver histology

\begin{tabular}{|c|c|c|c|c|c|c|}
\hline $\begin{array}{l}\text { HISTOPATHOLOGICAL } \\
\text { RESULTS }\end{array}$ & & $\begin{array}{c}\text { Number OF } \\
\text { PATIENTS }(\%)\end{array}$ & $\begin{array}{l}\text { SERUM OMENTIN } \\
{[\mathrm{NG} / \mathrm{ML}]}\end{array}$ & $\mathrm{P}$ & $\begin{array}{l}\text { LIVER OMENTIN/ } \\
\text { GAPDH }\end{array}$ & $\mathrm{P}$ \\
\hline \multirow{3}{*}{$\begin{array}{l}\text { Necro-inflammatory activity } \\
\text { grade }\end{array}$} & 1 & $13(18.8)$ & $13.92 \pm 3.94$ & \multirow[t]{3}{*}{ NS } & $0.20 \pm 0.12$ & \multirow[t]{3}{*}{ NS } \\
\hline & 2 & $38(55.1)$ & $15.04 \pm 3.98$ & & $0.67 \pm 1.48$ & \\
\hline & $3-4$ & $18(26.1)$ & $14.35 \pm 4.77$ & & $0.59 \pm 1.15$ & \\
\hline \multirow[t]{3}{*}{ Fibrosis stage } & 1 & $29(42.0)$ & $14.91 \pm 4.43$ & \multirow[t]{3}{*}{ NS } & $0.21 \pm 0.14$ & \multirow[t]{3}{*}{ NS } \\
\hline & 2 & $29(42.0)$ & $14.40 \pm 4.26$ & & $0.90 \pm 1.82$ & \\
\hline & $3-4$ & $11(15.9)$ & $14.83 \pm 2.94$ & & $0.65 \pm 0.89$ & \\
\hline \multirow[t]{2}{*}{ Steatosis presence } & present & $34(49.3)$ & $14.68 \pm 4.59$ & \multirow[t]{2}{*}{ NS } & $0.79 \pm 1.65$ & \multirow[t]{2}{*}{ NS } \\
\hline & absent & $35(50.7)$ & $14.68 \pm 3.73$ & & $0.36 \pm 0.74$ & \\
\hline \multirow{2}{*}{$\begin{array}{l}\text { Ballooning degeneration } \\
\text { grade }\end{array}$} & $0-1$ & $21(30.4)$ & $14.82 \pm 4.30$ & \multirow[t]{2}{*}{ NS } & $0.69 \pm 1.66$ & \multirow[t]{2}{*}{ NS } \\
\hline & 2 & $37(53.6)$ & $14.88 \pm 4.25$ & & $0.59 \pm 1.22$ & \\
\hline
\end{tabular}

\section{Discussion}

Adipokines have been found to exert a positive or negative impact on many biological processes, together with insulin sensitivity and inflammatory activity. The role of adipokines in $\mathrm{CHC}$ remains under intensive investigations $[4,16,17]$; thus analysis of omentin levels in serum together with its gene expression in liver tissue in CHC patients is the next step of this research. Omentin-1 (intelectin-1) is a newly identified adipokine that is highly and selectively expressed in visceral adipose tissue [22]. It falls under the category of being a "good adipokine": its serum levels are significantly decreased in patients with components of the metabolic syndrome (MS) and other disease conditions [34].

In our study serum omentin levels were significantly higher in CHC patients compared to the control group. The results were similar to those obtained by Nassif et al.'s study showing significantly higher serum omentin levels in CHC subjects. Nassif et al. additionally showed lowered serum omentin levels in CHC patients with T2DM. However, in those patients serum omentin concentration was still significantly higher than in diabetic patients without $\mathrm{CHC}$ [30]. The results of both studies suggest a pivotal role of omentin in $\mathrm{CHC}$.

The previous study by Pan et al. revealed significantly lower serum omentin levels in patients with DM. Moreover, serum omentin was negatively correlated with HOMA-IR, fasting insulin, fasting glucose and BMI [35]. Circulating omentin levels were negatively associated with a multiplicity of metabolic risk factors, suggesting that omentin acts as a biomarker of metabolic disorders [36]. Keeping in mind the strong influence of DM and obesity on serum omentin levels $[27,28]$, to avoid the possible influence of metabolic abnormalities associated with obesity and metabolic syndrome on omentin profile, we decided to include only non-diabetic, normal weight 
or overweight but not obese CHC patients. Contrary to Nassif et al. [30], in our study there was no correlation between serum omentin and HOMA-IR, fasting insulin and glucose. Our results indicate that HCV infection may be a predictor of increased omentin levels.

An additional aspect of the study is the direct impact of the virus on metabolic and inflammatory pathways - hence the choice of a homogeneous group of CHC patients consisting only of those infected with genotype $1 \mathrm{~b}$, in whom insulin resistance is the most distinct [37]. HCV genotype $1 \mathrm{~b}$ evokes insulin resistance by the direct influence on the intracellular insulin signaling pathway or by indirect mechanisms related to metabolic disturbances $[37,38]$. Steatosis in genotype $1 \mathrm{~b}$ infected patients results mainly from metabolic abnormalities. On the other hand, in genotype 3 infection steatosis is mainly viral derived, with less emphatic metabolic disturbances [38]. Therefore it is difficult to compare the influence of both $1 \mathrm{~b}$ and 3 genotypes on adipokine profile. In the study by Nassif et al. [30] there is no information about HCV genotype in analyzed patients. Therefore, this discrepancy may result from a different group of study participants. Contrary to the study by Nassif et al., our CHC patients also included overweight patients. The study by Nassif et al. analyzed Egyptian patients. This raises two further issues. The first is that in Egypt HCV genotype 4 is dominant [39]. We can suppose that patients analyzed by Nassif et al. were mainly infected with genotype 4 . The second issue is the racial divergence in serum omentin concentration. Mean plasma omentin-1 concentrations were higher in African Americans than in Caucasians [40]. This aspect may lead to a discrepancy in the obtained results, because our study included only Caucasians, whereas the study by Nassif et al. included Egyptian patients.

In relation to the lack of negative association between IR and omentin, which is contrary to the studies on patients with DM and obesity, it should be noted that IR in obese individuals is primarily metabolic and not viral, whereas in our study we preferred to concentrate on virally derived metabolic abnormalities. However, in obese $\mathrm{CHC}$ patients co-existence with nonalcoholic fatty liver disease (NAFLD) is common and exacerbates progression of viral disease by increasing IR and steatosis [4].

Important differences in circulating omentin levels related to estradiol and testosterone concentrations found by Luque-Ramírez et al. suggest sexual dimorphism of the serum adipokine profile. It is important to note that subjects with excess weight had lower omentin levels regardless of sex [29]. In our study group there were no important differences between men and women either in serum omentin levels or its gene liver expression. Hence, we did not find any difference in these parameters between men and women according to HOMA-IR or BMI, but in our study group there were no obese subjects, unlike in the study by Luque-Ramírez et al., where obese study subjects and those with excess weight were analyzed together [29]. In light of this, the relationships between sex hormone axes and the adipokine network need further analysis within a larger study group.

Adipokines, excreted primarily by adipose visceral tissue, are postulated to modify liver inflammation and fibrosis, especially by modulation of hepatic stellate cell biology [41]. Yilmaz et al. in their study, which included overweight or obese biopsy-proven NAFLD patients, $40 \%$ of whom were diabetic and over $60 \%$ of whom had metabolic syndrome, found a positive correlation of systemic serum omentin levels with C-reactive protein (CRP) and hepatocyte ballooning degeneration, suggesting its possible role in hepatocyte death [2]. This finding may be explained, at least partially, by the implication of omentin's role in immune and inflammatory responses as an agent generating anti-inflammatory signaling pathways [25, 26]. In our study, serum omentin levels were not associated with histopathological features of liver tissue specimens. Neither hepatocyte ballooning degeneration grade, necro-inflammatory activity and steatosis grade nor fibrosis stage were associated with serum omentin concentration. In our CHC patients, however, liver pathology was induced mainly by HCV infection while in the study by Yilmaz et al. the most important factor was abdominal obesity with a high amount of visceral adipose tissue. Thus serum omentin concentration was positively related to hepatocyte ballooning degeneration independent of insulin resistance and other features of the metabolic syndrome, which could suggest that it plays a role in the development and progression of chronic hepatitis. Hepatocyte ballooning degeneration as a hallmark of NAFLD evoking by enhanced oxidative stress is less evident in CHC. Moreover, as mentioned above, in $\mathrm{CHC}$ the impact of $\mathrm{HCV}$ on metabolic abnormalities and oxidative stress is strong. In NAFLD liver abnormalities result mainly from metabolic disturbances associated with metabolic syndrome. Due to different pathogenesis and various study groups, it seems difficult to compare the two studies, but the role of omentin in cell destruction and its influence on liver pathology in CHC should be further investigated.

Analysis of multiple tissues indicated that omentin is highly expressed in human omental fat, with much less in other organs but not in subcutaneous adipose tissue [21]. Administration of glucose and insulin to human omental adipose tissue explants resulted in a dose-dependent reduction of omentin-1 expression [42]. Thus, this may be a reason why NAFLD patients had higher levels of serum omentin. 
Eisinger $e t$ al. analyzed omentin levels in systemic venous, hepatic venous and portal venous sera in patients with liver cirrhosis and controls. Cirrhotic patients had higher portal vein omentin levels, which also were increased in systemic venous serum compared with controls, but there was no association with portal hypertension complications [43]. The main cause of cirrhosis in those patients was alcoholic hepatitis, with only three out of 34 having cirrhosis as a result of $\mathrm{CHC}$. In our $\mathrm{CHC}$ patients, different stages of fibrosis were revealed, but none of them correlated with serum omentin levels. This poses the question as to whether higher serum omentin levels resulted from slower liver metabolism of this molecule in chronic liver impairment.

Omentin expression in $\mathrm{CHC}$ patients' liver tissue has not been reported so far. Nevertheless, in our study group no connections have been shown, either with routinely analyzed histopathological parameters or with the sex of the patients. Omentin was found highly expressed in human visceral but not in subcutaneous adipose tissue, but Yang et al. did not reveal its expression in liver tissue using Northern analysis [21]. The authors applied procedures (TaqMan Gene Expression Assays (Hs00214137_m1)) which resulted in a hybridization product located at the $3^{\text {rd }}$ and $4^{\text {th }}$ exons' boundary, while in our experiment starters (Hs 00914740 g1 for omentin) hybridized with a fragment involving the $1^{\text {st }}$ and $2^{\text {nd }}$ exons' boundary. Moreover, in this assay the 5'UTR (5' untranslated region) is involved, which could stabilize the transcript and probably help in product detection. Further questions remain as to whether omentin expression in the liver is an important source of serum omentin in non-obese individuals and whether the $\mathrm{HCV}$ infection plays a stimulating/modulating role.

In summary, our study reported for the first time hepatic omentin expression in non-obese, non-diabetic $\mathrm{CHC}$ patients. The study did not find any important relationship between hepatic omentin and serum omentin levels and sex, metabolic features, routinely analyzed laboratory parameters or liver histology. These results suggest that neither serum omentin nor hepatic omentin influence metabolic disorders and/or liver pathology regardless of sex in CHC. Surprising$\mathrm{ly}$, there was also no correlation between serum omentin concentration and hepatic omentin expression. The lack of such a correlation points to different mechanisms regulating circulating omentin-1 concentration and hepatic omentin in CHC. Additional studies are required to determine whether levels of omentin are increased in $\mathrm{CHC}$ patients as a compensatory mechanism against increased IR or as a manifestation of poor omentin- 1 metabolism in the $\mathrm{HCV}$-infected liver, or both. Omentin liver tissue expression in $\mathrm{CHC}$ and its potential role in liver pathology require clarification also.

\section{The authors declare no conflict of interest.}

\section{References}

1. Raucci R, Rusolo F, Sharma A, et al. Functional and structural features of adipokine family. Cytokine 2013; 61: 1-14.

2. Yilmaz Y, Yonal O, Kurt R, et al. Serum levels of omentin, chemerin and adipsin in patients with biopsy-proven nonalcoholic fatty liver disease. Scand J Gastroenterol 2011; 46: 9197.

3. Bertolani C, Marra F. The role of adipokines in liver fibrosis. Pathophysiology 2008; 15: 91-101.

4. Kukla M, Mazur W, Bułdak RJ, Zwirska-Korczala K. Potential role of leptin, adiponectin and three novel adipokines - visfatin, chemerin and vaspin - in chronic hepatitis. Mol Med 2011; 17: 1397-1410.

5. Lago F, Gómez R, Gómez-Reino JJ, et al. Adipokines as novel modulators of lipid metabolism. Trends Biochem Sci 2009; 34 : 500-510.

6. Fartoux L, Poujol-Robert A, Guéchot J, et al. Insulin resistance is a cause of steatosis and fibrosis progression in chronic hepatitis C. Gut 2005; 54: 1003-1008.

7. Yoneda M, Saito S, Ikeda T, et al. Hepatitis C virus directly associates with insulin resistance independent of the visceral fat area in nonobese and nondiabetic patients. J Viral Hepat 2007; 14: 600-607.

8. Adinolfi LE, Durante-Mangoni E, Zampino R, Ruggiero G. Review article: hepatitis $C$ virus-associated steatosis-pathogenic mechanisms and clinical implications. Aliment Pharmacol Ther 2005; 22 (Suppl 2): 52-55.

9. Kukla M, Gabriel A, Sabat D, et al. Association between liver steatosis and angiogenesis in chronic hepatitis C. Pol J Pathol 2010; 61: 154-160.

10. Bernsmeier C, Heim MH. Insulin resistance in chronic hepatitis C: mechanisms and clinical relevance. Swiss Med Wkly 2009; 139: 678-684.

11. Mehta SH, Brancati FL, Sulkowski MS, et al. Prevalence of type 2 diabetes mellitus among persons with hepatitis $C$ virus infection in the United States. Ann Intern Med 2000; 133: 592-599.

12. Kukla M, Sawczyn T, Żwirska-Korczala K, Jarosz M. Pathomechanism of insulin resistance in chronic hepatitis C. Przegl Gastroenterol 2011; 6: 284-289.

13. Perlemuter G, Sabile A, Letteron P, et al. Hepatitis C virus core protein inhibits microsomal triglyceride transfer protein activity and very low density lipoprotein secretion: a model of viral-related steatosis. FASEB J 2002; 16: 185-194.

14. Hui JM, Sud A, Farrell GC, et al. Insulin resistance is associated with chronic hepatitis $\mathrm{C}$ virus infection and fibrosis progression [corrected]. Gastroenterology 2003; 125: 1695-1704.

15. Zwirska-Korczala K, Kukla M, Ziółkowski A, et al. Leptin, neopterin and hepatocyte growth factor as markers of fibrosis and inflammatory activity in chronic hepatitis C. E\&C Hepatology 2005; 1: 60-65.

16. Kukla M, Zwirska-Korczala K, Gabriel A, et al. Chemerin, vaspin and insulin resistance in chronic hepatitis C. J Viral Hepat 2010; 17: 661-667.

17. Kukla M, Zwirska-Korczala K, Gabriel A, et al. Visfatin serum levels in chronic hepatitis C patients. J Viral Hepat 2010; 17: 254-260.

18. Marra F, Bertolani C. Adipokines in liver diseases. Hepatology 2009; 50: 957-969.

19. Kukla M, Berdowska A, Stygar D, et al. Serum FGF21 and RBP4 levels in patients with chronic hepatitis C. Scand J Gastroenterol 2012; 47: 1037-1047. 
20. Kukla M, Waluga M, Sawczyn T, et al. Serum vaspin may be a good indicator of fibrosis in chronic hepatitis $\mathrm{C}$ and is not altered by antiviral therapy. Pol J Pathol 2012; 63: 213-220.

21. Yang RZ, Lee $\mathrm{MJ}, \mathrm{Hu} \mathrm{H}$, et al. Identification of omentin as a novel depot-specific adipokine in human adipose tissue: possible role in modulating insulin action. Am J Physiol Endocrinol Metab 2006; 290: E1253-1261.

22. Schäffler A, Neumeier M, Herfarth H, Fürst A, Schölmerich J, Büchler C. Genomic structure of human omentin, a new adipocytokine expressed in omental adipose tissue. Biochim Biophys Acta 2005; 1732: 96-102.

23. Rabe K, Lehrke M, Parhofer KG, Broedl UC. Adipokines and insulin resistance. Mol Med 2008; 14: 741-751.

24. Yamawaki H, Kuramoto J, Kameshima S, et al. Omentin, a novel adipocytokine inhibits TNF-induced vascular inflammation in human endothelial cells. Biochem Biophys Res Commun 2011; 408: 339-343.

25. Tan BK, Adya R, Randeva HS. Omentin: a novel link between inflammation, diabesity, and cardiovascular disease. Trends Cardiovasc Med 2010; 20: 143-148.

26. Yamawaki H. Vascular effects of novel adipocytokines: focus on vascular contractility and inflammatory responses. Biol Pharm Bull 2011; 34: 307-310.

27. de Souza Batista CM, Yang RZ, Lee MJ, et al. Omentin plasma levels and gene expression are decreased in obesity. Diabetes 2007; 56: 1655-1661.

28. Auguet T, Quintero Y, Riesco D, et al. New adipokines vaspin and omentin. Circulating levels and gene expression in adipose tissue from morbidly obese women. BMC Med Genet 2011; 12: 60 .

29. Luque-Ramírez M, Martínez-García MÁ, Montes-Nieto R, et al. Sexual dimorphism in adipose tissue function as evidenced by circulating adipokine concentrations in the fasting state and after an oral glucose challenge. Hum Reprod 2013; 28: 19081918.

30. Nassif WMH, Amin AI, Hassan ZA, Abdelaziz DHA. Changes of serum omentin-1 levels and relationship between omentin-1 and insulin resistance in chronic hepatitis $\mathrm{C}$ patients. EXCLI Journal 2013; 12: 924-932.

31. Scheuer PJ. The nomenclature of chronic hepatitis: time for a change. J Hepatol 1995; 22: 112-114.

32. Brunt EM, Janney CG, Di Bisceglie AM, Neuschwander-Tetri BA, Bacon BR. Nonalcoholic steatohepatitis: a proposal for grading and staging the histological lesions. Am J Gastroenterol 1999; 94: 2467-2474

33. Kleiner DE, Brunt EM, Van Natta M, et al. Design and validation of a histological scoring system for nonalcoholic fatty liver disease. Hepatology 2005; 41: 1313-1321.

34. Jaikanth C, Gurumurthy P, Cherian KM, Indhumathi T. Emergence of omentin as a pleiotropic adipocytokine. Exp Clin Endocrinol Diabetes 2013; 121: 377-383.

35. Pan HY, Guo L, Li Q. Changes of serum omentin-1 levels in normal subjects and in patients with impaired glucose regulation and with newly diagnosed and untreated type 2 diabetes. Diabetes Res Clin Pract 2010; 88: 29-33.

36. Shibata R, Ouchi N, Takahashi R, et al. Omentin as a novel biomarker of metabolic risk factors. Diabetol Metab Syndr 2012; 4: 37.

37. Knobler H, Schihmanter R, Zifroni A, et al. Increased risk of type 2 diabetes in noncirrhotic patients with chronic hepatitis C virus infection. Mayo Clin Proc 2000; 75: 355-359.

38. Thompson AJ, Patel K, Chuang WL, et al. Viral clearance is associated with improved insulin resistance in genotype 1 chronic hepatitis C but not genotype 2/3. Gut 2012; 61: 128-134.

39. Gower E, Estes C, Blach S, Razavi-Shearer K, Razavi H. Global epidemiology and genotype distribution of the hepatitis $\mathrm{C}$ virus infection. J Hepatol 2014; 61 (Suppl. 1): S45-57.

40. Vu A, Sidhom MS, Bredbeck BC, et al. Evaluation of the relationship between circulating omentin-1 concentrations and components of the metabolic syndrome in adults without type 2 diabetes or cardiovascular disease. Diabetol Metab Syndr 2014; 6: 4.

41. Marra F, Navari N, Vivoli E, Galastri S, Provenzano A. Modulation of liver fibrosis by adipokines. Dig Dis 2011; 29: 371376.

42. Tan BK, Adya R, Farhatullah S, et al. Omentin-1, a novel adipokine, is decreased in overweight insulin-resistant women with polycystic ovary syndrome: ex vivo and in vivo regulation of omentin-1 by insulin and glucose. Diabetes 2008; 57: 801808.

43. Eisinger K, Krautbauer S, Wiest R, et al. Portal vein omentin is increased in patients with liver cirrhosis but is not associated with complications of portal hypertension. Eur J Clin Invest 2013; 43: 926-932.

\section{Address for correspondence}

\section{Michał Kukla}

Medical University of Silesia

Department of Gastroenterology and Hepatology

Medyków 14

40-752 Katowice

tel. +48327894401

e-mail: kuklamich@poczta.onet.pl 